\title{
Autoimmune limbic encephalitis in 39 patients: immunophenotypes and outcomes
}

\author{
L Bataller, K A Kleopa, G F Wu, J E Rossi, M R Rosenfeld, J Dalmau
}

See Editorial Commentary, p 332

J Neurol Neurosurg Psychiatry 2007;78:381-385. doi: 10.1136jnnp.2006.100644

See end of article for authors' affiliations

Correspondence to: Correspondence to:
J Dalmau, Department of Neurology, Division of Neuro-oncology, $3 \mathrm{~W}$ Gates, University of Pennsylvania, 3400 Spruce Street, Philadelphia, PA 19104, USA; josep. dalmau@uphs.upenn.edu

Received 24 June 2006 Revised 8 August 2006 Accepted

11 September 2006

Published Online First

15 September 2006

.....................
Background: About $40 \%$ of patients with limbic encephalitis do not have detectable CNS antibodies. Some of these patients have immune-mediated limbic encephalitis, but their frequency is unknown.

Aims: (1) To determine the spectrum of limbic encephalitis identified on clinical grounds in a single institution, and compare it with that in patients referred for antibody analysis. (2) To correlate clinical outcomes with the cellular location of the autoantigens.

Methods: Prospective clinical case studies. Immunohistochemistry with rat brain, live hippocampal neurones, HeLa cells expressing $\mathrm{Kv}$ potassium channels and immunoblot.

Results: In 4 years, 17 patients were identified in the Hospital of the University of Pennsylvania, Philadelphia, USA, and the serum or CSF samples of 22 patients diagnosed elsewhere were also studied. 9 of our 17 (53\%) patients had antibodies to known neuronal antigens (paraneoplastic or voltage gated potassium channels (VGKCs)) and $5(29 \%)$ to novel cell-membrane antigens (nCMAg) typically expressed in the hippocampus and sometimes in the cerebellum. Considering the entire series, 19 of $39(49 \%)$ patients had antibodies to known antigens, and $17(44 \%)$ to nCMAg. Follow-up (2-48 months, median 19 months) was available for 35 patients. When compared with patients with antibodies to intraneuronal antigens, a significant association with response to treatment was found in those with antibodies to cell-membrane antigens in general (VGKC or $n C M A g, p=0.003)$ or to $n C M A g(p=0.006)$.

Conclusions: (1) $82 \%$ of patients with limbic encephalitis prospectively identified on clinical grounds had CNS antibodies; (2) responsiveness to treatment is not limited to patients with VGKC antibodies; (3) in many patients ( $29 \%$ from a single institution), the autoantigens were unknown but were found to be highly enriched in neuronal cell membranes of the hippocampus; and (4) these antibodies are associated with a favourable outcome.
U ntil the mid-1990s, most cases of non-viral limbic encephalitis were considered to be paraneoplastic. ${ }^{1}$ However, there are an increasing number of reports of patients whose clinical, radiological and CSF findings suggest limbic encephalitis but whose diagnostic tests and follow-up exclude an underlying cancer. ${ }^{23}$ Evidence that some of these disorders are immune mediated includes the recent description of limbic encephalitis associated with antibodies to voltagegated potassium channels (VGKC), ${ }^{4}$ the occasional association with systemic autoimmune disorders ${ }^{5}$ and frequent response to immunotherapy. ${ }^{6}$ Recent studies show that in addition to antiVGKC, there are other limbic encephalitis-related antibodies that target novel cell-membrane antigens (nCMAg). ${ }^{78}$ These findings have broadened the spectrum of limbic encephalitis and suggest extensive antigen diversity. The relative frequency of these disorders is unknown because they are often unrecognised or have been excluded from most series of limbic encephalitis whose inclusion criteria are limited to patients with specific types of tumours or antibodies. ${ }^{14-12}$ Also, there is no single prospective institutional study reporting clinical experience with all of these disorders.

In this study, we review the clinical types and immunophenotypes of 39 patients with limbic encephalitis studied in the past 4 years, focusing on the relative distribution of patients seen by us in a single institution $(n=17)$ and those whose serum or CSF was referred to us for antibody analysis $(\mathrm{n}=22)$. We also examine the clinical implications of identifying antibodies to known antigens and nCMAg.

\section{METHODS}

This study included patients who were seen by us between January 2002 and January 2006 at the Hospital of the University of Pennsylvania (HUP), Philadelphia, Pennsylvania, USA, and patients whose clinical information, MRI scans, and sera or CSF samples were sent to us for consultation concerning of a recent onset disorder $(<12$ weeks' duration) consistent with focal limbic encephalitis or multifocal encephalitis with predominant symptoms of limbic dysfunction. These included confusion, seizures, short-term memory loss or psychiatric symptoms in association with one or more of the following: (1) neuroimaging (MRI or positron emission tomography) evidence of temporal lobe involvement; (2) CSF inflammatory abnormalities (pleocytosis, increased protein concentration or oligoclonal bands); or (3) detection of antibodies that occur in association with limbic encephalitis. All patients were examined for systemic cancer using whole-body computed tomography or fluorodeoxyglucosepositron emission tomography, and studied for autoimmune disorders with the following tests: antinuclear antibody, antidouble-stranded DNA, Smith/Rnp, Sjogren's (SSA,SSB), antineutrophilic cytoplasmic antibodies, anticardiolipin, antithyroglobulin and antimicrosomal (thyroperoxidase) antibodies. Patients with CNS infection or metastases were excluded from analysis. Eleven cases have been reported previously. ${ }^{713}$ All studies were approved by the University of Pennsylvania institutional review board. Fisher's exact test was used in statistical analyses.

\section{Analysis of CNS antibodies}

Serum and CSF samples were available from 35 patients; only serum or CSF was available from two patients each.

Abbreviations: CNS, central nervous system; HUP, Hospital of the University of Pennsylvania; MRI, magnetic resonance imaging; nCMAg, novel cell-membrane antigen; VGKC, voltage-gated potassium channel 

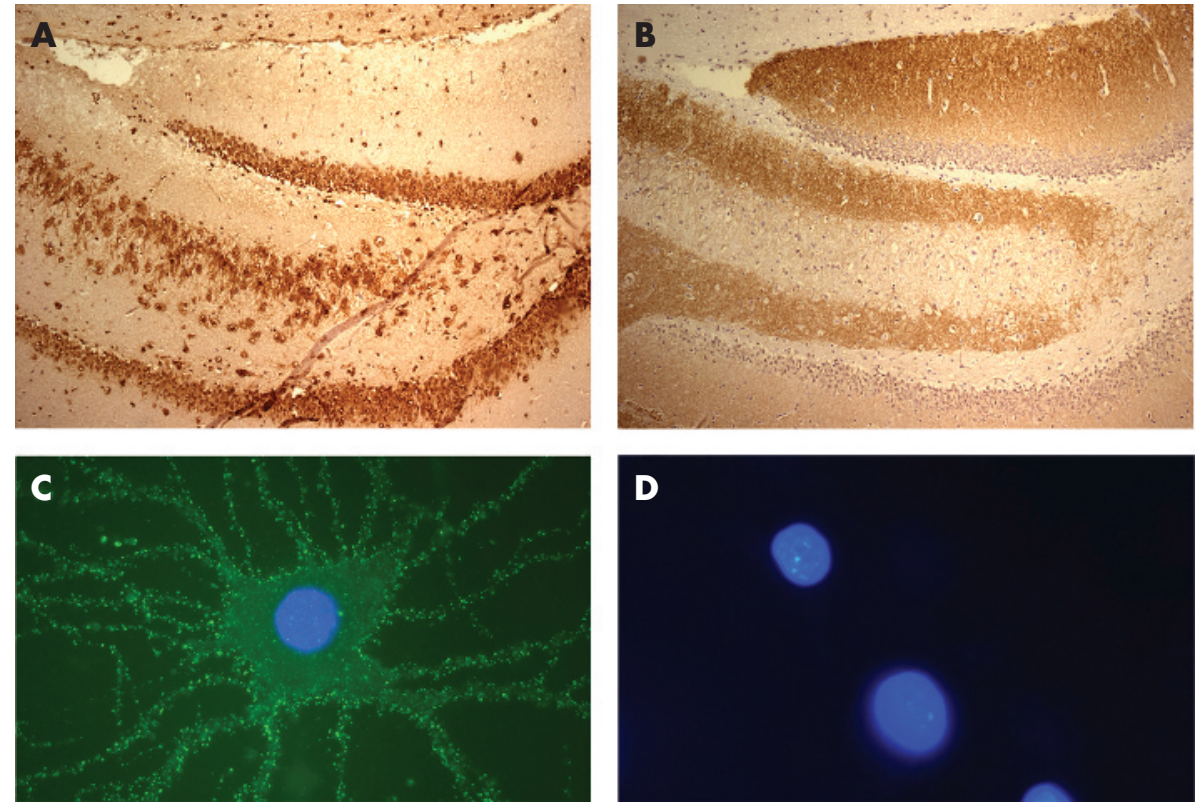

Figure 1 Immunohistochemical analysis of antibodies associated with limbic encephalitis. (A,B) Consecutive coronal sections of rat hippocampus immunolabelled with serum of a patient with (A) anti-Hu antibodies and (B) antibodies to novel cell-membrane antigen (nCMAg; unknown antigen). (B) Reactivity predominates in the neuropil, sparing neuronal cell bodies. (C,D) Live rat hippocampal neuronal cultures incubated with (C) CSF from a patient with limbic encephalitis, ovarian teratoma and antibodies to $\mathrm{nCMAg}$ and (D) CSF from a patient with stroke (used as control). The intense immunolabelling of $\mathrm{nCMAg}$ with the neuronal cell membrane and absence of reactivity of the control CSF are evident. (A,B) Avidin-biotin peroxidase method; counterstained with a haematoxylin $200 \times$. (C,D) Immunofluorescence method; nuclei demonstrated by DAPI, $800 \times$ oil immersion lens.

Immunohistochemistry was performed using previously reported methods on the following: (1) rat brain sections fixed with acetone or methanol-acetone (serum 1:500; CSF 1:10) ${ }^{14}$; (2) rat brain sections pre-fixed with paraformaldehyde (PFA) (serum 1:250; CSF 1:10) ${ }^{7}$; and (3) live rat hippocampal neuronal cultures (serum 1:1000; CSF 1:50). ${ }^{8}$ Additional studies included immunoblot with proteins extracted from purified human neurones, and recombinant $\mathrm{HuD}, \mathrm{Mal}$ and Ma2, CRMP5 and amphiphysin. ${ }^{15}$ The presence or absence of VGKC was confirmed by radioimmunoassay at Athena Diagnostics (Worcester, MA, USA), and with transfected HeLa cells expressing Kvl.1, Kvl.2, Kvl.4 and Kv1.6 VGKC subunits as reported recently. ${ }^{16}$

\section{RESULTS}

\section{Antibodies}

In all, 39 patients were identified with limbic encephalitis: 17 were seen at the HUP and 22 at other institutions. Table 1 shows the associated antibodies, methods used to demonstrate them and the location of the antigens. Fourteen patients had antibodies to intraneuronal antigens (anti-Hu, $\mathrm{n}=7$; anti-Ma2, $\mathrm{n}=6$; and unknown, $\mathrm{n}=1$ ) and all were identified with standard immunohistochemistry with methanol-acetonefixed tissue (fig 1A) or immunoblot studies. Five patients had
anti-VGKC, demonstrated by immunohistochemistry with PFA-fixed tissue and radioimmunoassay (range 195-62l, median 320; positive $>173 \mathrm{pmol}$ ). Seventeen patients had novel antibodies that were detected only with immunohistochemistry with PFA-fixed tissue (fig 1B) and cultures of live hippocampal rat neurones (all with intense immunolabelling of cell membrane antigens; nCMAg; fig lC,D). The patterns of rat brain immunolabelling of these antibodies have been reported previously: nine were highly restricted to the neuropil of hippocampus (all patients with ovarian teratoma), ${ }^{8}$ and six had additional reactivity with the molecular layer of the cerebellum and to a lesser degree of the cerebral cortex. ${ }^{7}$ Three patients had no detectable antibodies.

Of the five patients with VGKC antibodies, three were seen at the HUP and underwent additional examinations to determine which specific Kv subunits were targeted by the antibodies. One patient had antibodies to Kvl.l, another to Kvl.l and Kvl.2, and the third to Kvl.l and Kvl.6.

All serum or CSF samples of 17 patients with anti-nCMAg were negative by the radioimmunoassay, although one showed mild reactivity with cells expressing Kvl.4 (data not shown) and another with cells expressing Kvl.6 (both patients had encephalitis associated with ovarian teratoma). Both these samples produced an identical pattern of hippocampal

Table 1 Antibodies, methods of detection and antigen location

\begin{tabular}{|c|c|c|c|}
\hline Occurrence of antibodies & Type of antibody & Studies that showed the antibodies & Location of antigens \\
\hline Characterised antibodies, $n=19$ & $\begin{array}{l}\text { anti-Hu, } n=7 \text {; anti-Ma2, } n=6 \text {; } \\
\text { atypical, } n=1 \\
\text { VGKC, } n=5\end{array}$ & $\begin{array}{l}\text { IH (methanol-acetone) and immunoblot with } \\
\text { neuronal proteins } \\
\text { IH (PFA); IC with cells expressing Kv subunits; } \\
\text { and radioimmunoassay }\end{array}$ & $\begin{array}{l}\text { Intracellular, } n=14 \\
\text { Cell membrane, } n=22\end{array}$ \\
\hline \multicolumn{2}{|c|}{ Partially characterised antibodies, $n=17 n C M A g, n=17$} & IH (PFA); and IC with live neurones & - \\
\hline
\end{tabular}

IC; immunocytochemistry; IH: immunohistochemistry; nCMAg, novel cell-membrane antigen; PFA, paraformaldehyde. 
immunolabelling ${ }^{8}$ that was clearly different from that obtained with polyclonal Kv1.4 or Kvl.6 antibodies, indicating that the main targets were other (unknown) hippocampal antigens. None of the antibodies to nCMAg of the other 15 patients reacted with cells expressing any of the indicated $\mathrm{Kv}$ subunits.

All antibodies (including anti-VGKC) were identified in the serum and CSF (if available). However, antibodies to nCMAg were technically easier to detect in the CSF than in serum. In 3 of 17 patients with antibodies to nCMAg, the initial studies demonstrated the antibodies only in the CSF; in all the three cases repeat studies with concentrated sera (dilution 1:100) showed the hippocampal neuropil reactivity over diffuse background staining. This background staining was similar to that found in normal control sera when used at a 1:100 dilution in PFA-fixed tissue. No background staining occured with the CSF of patients or controls.

\section{Clinical-immunological features}

Table 2 shows the clinical and immunological features of the 17 patients seen at the HUP. Of these 17 patients, two were referred from other institutions to one of the authors on suspicion of a paraneoplastic disorder; the other 15 patients were diagnosed during their admission for neurological symptoms of unknown aetiology $(\mathrm{n}=12)$ or in the outpatient clinic $(n=3)$. None of these 15 patients was specifically referred to the HUP or any of the authors for a paraneoplastic disorder. We included six patients with antibodies to intracellular antigens (anti-Hu, $\mathrm{n}=4$; anti-Ma2, $\mathrm{n}=1$; and atypical antibodies, $\mathrm{n}=1$ ), eight with antibodies to neuronal cellmembrane antigens (to nCMAg, $\mathrm{n}=5$ and to VGKC, $\mathrm{n}=3$ ), and three without detectable antibodies.

During the same time period, we received clinical information, sera or CSF samples of 22 patients with limbic encephalitis from other institutions (table 3 ). These studies resulted in the identification of patients with antibodies to intracellular antigens $(\mathrm{n}=8 ; \mathrm{Hu}, \mathrm{n}=3$; Ma2, $\mathrm{n}=5), \operatorname{nCMAg}(\mathrm{n}=12)$ and $\operatorname{VGKC}(\mathrm{n}=2)$.

\section{Experience at a single institution: comparison with referred cases}

Comparing the immunophenotypes of patients seen at the HUP with the referred cases, the two main differences were: (1) the relatively lower frequency of patients with antibodies to Ma2 (7\%) and to nCMAg (36\%) at the HUP compared with the referrals (23\% with antibodies to Ma2 and 55\% to nCMAg), and (2) the younger age of the patients in this referral group, in which the main tumours were germ-cell neoplasm of the testis ( $\mathrm{n}=4$; age $23-36$, median 25 years) and ovarian teratoma ( $\mathrm{n}=8$; age 14-40, median 29 years), both histological types typically occurring in young patients (tables 2 , and 3 ).

\section{Overview of immunophenotypes}

The main differences among immunophenotypes of all 39 patients were as follows:

1. The high frequency of abnormal movements $(41 \%)$ and decreased level of consciousness and hypoventilation $(59 \%)$ in patients with nCMAg

2. The tumour associations: $90 \%$ of patients with antibodies to intracellular autoantigens had tumours of the lung or testes, $76 \%$ of patients with antibodies to nCMAg had teratomas or tumours of the thymus, and only $20 \%$ of patients with VGKC had a tumour

3. The low frequency of "typical" limbic or medial temporal lobe hyperintensities in MRI T2 or fluid attenuation inversion recovery in patients with antibodies to nCMAg (35\%) when compared with patients with antibodies to intracellular antigens $(57 \%)$ or anti-VGKC (100\%)

4. The better clinical outcome in patients with antibodies to nCMAg and VGKC.

\section{Treatment and clinical outcome}

Clinical information and adequate follow-up was obtained from 35 patients. Of 29 patients with tumours, five did not receive

Table 2 Clinical features and immunological findings in patients with limbic encephalitis seen at the Hospital of the University of Pennsylvania $(n=17)$

\begin{tabular}{|c|c|c|c|c|c|c|c|}
\hline $\begin{array}{l}\text { Total patients } \\
\text { (antigen) }\end{array}$ & $\begin{array}{l}\text { Sex; age range } \\
\text { (median), years }\end{array}$ & $\begin{array}{l}\text { Other neurological } \\
\text { features or symptoms }\end{array}$ & $\begin{array}{l}\text { CSF } \\
\text { findings, } \\
\text { range } \\
\text { (median) }\end{array}$ & $\begin{array}{l}\text { Typical } \\
\text { "limbic" MRI } \\
\text { abnormality }\end{array}$ & Cancer & $\begin{array}{l}\text { Immunotherapy other } \\
\text { than corticosteroids }\end{array}$ & $\begin{array}{l}\text { Neurological } \\
\text { outcome }\end{array}$ \\
\hline $\begin{array}{l}\mathrm{Hu}, \mathrm{n}=4 ; \mathrm{Ma} 2 \\
\mathrm{n}=1 ; \text { atypical, } \\
n=1\end{array}$ & $5 \mathrm{M}, 1 \mathrm{~F} ; 28-65(63)$ & $\begin{array}{l}\text { Encephalomyelitis, } n=2 ; \\
\text { sensory neuronopathy, } \\
n=3 ; \\
2 \text { cerebellar/or } \\
\text { brainstem, } n=2\end{array}$ & $\begin{array}{l}\text { *WBC 0-81 } \\
\text { (3); } \\
\text { †Prot 74-150 } \\
\text { (79) }\end{array}$ & $\begin{array}{l}\text { Typical, } n=4 \\
\text { other, } n=2 \ddagger\end{array}$ & $\begin{array}{l}\text { SCLC, } \mathrm{n}=4 ; \\
\text { testicular, } \mathrm{n}=1 ; \\
\text { thyroid, } \mathrm{n}=1\end{array}$ & $\begin{array}{l}\text { IVlg, } n=1 \\
\text { CTX, } n=2 ; \\
\text { IVlg+PEX +Rituximab+ } \\
\text { Aza, } n=1\end{array}$ & $\begin{array}{l}\text { PI (Ma2), } n=1 ; \\
\text { stable }(H u), n=1 ; \\
\text { died, } n=4\end{array}$ \\
\hline $\mathrm{nCMAg}, \mathrm{n}=5$ & $5 F ; 24-65(44)$ & $\begin{array}{l}\text { Diffuse encephalitis, } n=2 \text {; } \\
\text { decreased level of } \\
\text { consciousness and } \\
\text { hypoventilation, } n=1 ; \\
\text { chorea/dystonia, } n=1\end{array}$ & $\begin{array}{l}\text { WBC 15-49 } \\
(30) ; \\
\text { Prot 18-97 } \\
\text { (67) }\end{array}$ & $\begin{array}{l}\text { fOther, } n=4 \\
\text { normal, } n=1\end{array}$ & $\begin{array}{l}\text { Teratoma, } \mathrm{n}=3 \\
\text { (ovary, } \mathrm{n}=2 ; \\
\text { thymus, } \mathrm{n}=1 \text { ); } \\
\text { cancer of thymus, } \\
\mathrm{n}=1 ; \\
\text { no tumour, } \mathrm{n}=1\end{array}$ & $\begin{array}{l}\text { IVlg, } n=1 ; P E X \\
n=1 ; \operatorname{IVlg}+P E X, n=1\end{array}$ & $\begin{array}{l}\mathrm{Cl}(\mathrm{n}=4, \\
\text { teratoma, } \mathrm{n}=3 \text {, } \\
\text { cancer of thymus, } \\
\mathrm{n}=1 \text { ); } \\
\text { deteriorated } \\
\text { (no tumour), } \mathrm{n}=1\end{array}$ \\
\hline VGKC, $n=3$ & $2 M, 1 F ; 38-60(58)$ & $\begin{array}{l}\text { Peripheral nerve } \\
\text { hyperexcitability, } n=1\end{array}$ & $\begin{array}{l}\text { WBC 0-4 } \\
\text { (2); Prot } \\
45-79(63)\end{array}$ & Typical, $n=3$ & Prostate, $n=1$ & IVlg, $n=2$ & $\begin{array}{l}\mathrm{Cl}, \mathrm{n}=2 ; \\
\text { stable, } \mathrm{n}=1\end{array}$ \\
\hline $\begin{array}{l}\text { No antibodies, } \\
n=3\end{array}$ & $1 \mathrm{M}, 2 \mathrm{~F} ; 28-60(40)$ & $\begin{array}{l}\text { Multiple (cerebellar } \\
\text { myelopathy neuropathy), } \\
n=1\end{array}$ & $\begin{array}{l}\text { WBC 2-119 } \\
\text { (10); Prot } \\
32-132 \text { (47) }\end{array}$ & $\begin{array}{l}\text { Typical, } n=2 \\
\text { other, } n=1\end{array}$ & Prostate, $n=1$ & Aza, $n=1$ & $\mathrm{Cl}, \mathrm{n}=3$ \\
\hline
\end{tabular}

Aza, azathioprine; $\mathrm{Cl}$, complete improvement; CTX, cyclophosphamide; F, female; IVlg, intravenous immunoglobulin; $\mathrm{M}$, male; $\mathrm{nCMAg}$, novel cell-membrane antigen $\mathrm{PI}$, partial improvement; PEX, plasma exchange; SCLC, small-cell lung cancer; VGKC, voltage -gated potassium channels; WBC, white blood cells. *WBC (white cell count) per $\mu \mathrm{l}$; normal value $<4 / \mu \mathrm{l}$.

†Prot (protein concentration) in $\mathrm{mg} / \mathrm{dl}$; normal value $16-46 \mathrm{mg} / \mathrm{dl}$.

‡Other: fluid attenuation inversion recovery or T2 abnormalities in regions other than medial temporal lobes. 
Table 3 Clinical features and immunological findings in patients with limbic encephalitis seen at other institutions $(n=22)$

\begin{tabular}{|c|c|c|c|c|c|c|c|}
\hline $\begin{array}{l}\text { Total patients } \\
\text { (antigen) }\end{array}$ & $\begin{array}{l}\text { Sex; age } \\
\text { range } \\
\text { (median) }\end{array}$ & $\begin{array}{l}\text { Other neurological } \\
\text { features or symptoms }\end{array}$ & $\begin{array}{l}\text { CSF finding range } \\
\text { (median) }\end{array}$ & $\begin{array}{l}\text { Typical "limbic" } \\
\text { MRI abnormality }\end{array}$ & Cancer & $\begin{array}{l}\text { Immunotherapy other } \\
\text { than } \\
\text { corticosteroids }\end{array}$ & Neurological outcome \\
\hline $\begin{array}{l}\mathrm{Hu}, \mathrm{n}=3 \\
M a 2, \mathrm{n}=5\end{array}$ & $\begin{array}{l}6 \mathrm{M}, 2 \mathrm{~F} \\
23-67(36)\end{array}$ & $\begin{array}{l}\text { Encephalomyelitis, } \\
\mathrm{n}=1 ; \text { brainstem, } \\
\mathrm{n}=2 ; \text { hypothalamic, } \\
\mathrm{n}=1\end{array}$ & $\begin{array}{l}\text { *WBC 2-20 (18); } \\
\text { †Prot 30-747 (80) }\end{array}$ & $\begin{array}{l}\text { Typical, } n=4 \\
\text { other, } n=3 \\
\text { NA, } n=1\end{array}$ & $\begin{array}{l}\text { SCLC, } n=3 ; \\
\text { non-SCLC, } n=1 \\
\text { testicular, } n=4\end{array}$ & $\begin{array}{l}\text { PEX+IVlg, } n=1 \\
\text { PEX, } n=1 \\
\text { IVlg, } n=3\end{array}$ & $\begin{array}{l}\text { PI (Ma2), } n=1 ; \\
\text { Cl }(H u), n=1 ; \\
\text { stable }(M a 2), n=1 ; \\
\text { died (Ma2, } n=2 ; \\
\text { Hu, } n=1), n=3 ; \\
\text { no follow-up, } n=2\end{array}$ \\
\hline $\begin{array}{l}\mathrm{nCMAg} \\
\mathrm{n}=12\end{array}$ & $\begin{array}{l}2 \mathrm{M}, 10 \mathrm{~F} \\
3-40 \text { (29) }\end{array}$ & $\begin{array}{l}\text { Decreased level } \\
\text { of consciousness and } \\
\text { hypoventilation, } n=9 \text {; } \\
\text { dystonia/ } \\
\text { choreoathetosis, } n=6 \text {; } \\
\text { stiff-person, } n=1\end{array}$ & $\begin{array}{l}\text { WBC 7-189 (20); } \\
\text { Prot 30-92 (50) }\end{array}$ & $\begin{array}{l}\text { Typical, } n=6 ; \\
\text { other, } n=4 ; \\
\text { normal, } n=2\end{array}$ & $\begin{array}{l}\text { Thymoma, } \mathrm{n}=1 \text {; } \\
\text { teratoma of the } \\
\text { ovary, } \mathrm{n}=8 ; \\
\text { no tumour, } \mathrm{n}=1 ; \\
\text { not known, } \mathrm{n}=2\end{array}$ & $\begin{array}{l}\text { PEX, } n=3 ; \\
\text { IVlg, } n=2 ; \\
\text { PEX+IVlg, } n=2 ; \\
\text { PEX+IVlg+CTX, } n=2\end{array}$ & $\begin{array}{l}\text { PI (ovarian teratoma, } \mathrm{n}=3 \text {; } \\
\text { thymoma, } \mathrm{n}=1 \text {; } \\
\text { no tumour, } \mathrm{n}=1 \text { ), } \mathrm{n}=5 ; \\
\mathrm{Cl} \text { (ovarian teratoma), } \mathrm{n}=3 \text {; } \\
\text { died (ovarian } \\
\text { teratoma), } \mathrm{n}=2 ; \\
\text { no follow-up, } \mathrm{n}=2\end{array}$ \\
\hline VGKC, $n=2$ & $\begin{array}{l}2 M ; \\
58 \text { and } 59\end{array}$ & - & $\begin{array}{l}\text { WBC 0-2; } \\
\text { Prot normal }\end{array}$ & Typical, $n=2$ & No cancer & $\begin{array}{l}\text { PEX, } n=1 \\
\text { IVlg, } n=1\end{array}$ & $\begin{array}{l}\mathrm{Cl} \text { (relapsing } \\
\text { syndrome, } \mathrm{n}=1 \text { ), } \mathrm{n}=2\end{array}$ \\
\hline
\end{tabular}

$\mathrm{Cl}$, complete improvement; CTX, cyclophosphamide; F, female; IVlg, intravenous immunoglobulin; $\mathrm{M}$, male; NA, not available; $\mathrm{nCMAg}$, novel cell-membrane antigen; PEX, plasma exchange; PI, partial improvement; SCLC, small-cell lung cancer; VGKC, voltage-gated potassium channels.

*WBC (white blood count) per $\mu$ l; normal value $<4 / \mu$ l.

†Prot (protein concentration) in $\mathrm{mg} / \mathrm{dl}$; normal value $16-46 \mathrm{mg} / \mathrm{dl}$.

oncologic therapy (small-cell lung cancer, $\mathrm{n}=2$; teratomas, $n=3$ ); four of these patients died of neurological progression and one (ovarian teratoma) recovered after receiving corticosteroids and intensive care support. The other 24 patients had oncological therapy (tumour resection, $\mathrm{n}=18$; chemotherapy, $\mathrm{n}=3$; both, $\mathrm{n}=1$ ). All 35 patients received corticosteroids, 10 intravenous immunoglobulin, 6 plasma exchange, 7 intravenous immunoglobulin and plasma exchange (3 also received other immunosuppressants), 2 cyclophosphamide and 1 azathioprine.

The median follow-up was 19 (range 2-48) months. These patients were considered to be completely improved if they were able to return to work or normal daily activities. Patients were considered to be partially improved if they were not able to return to work but could function independently at home or return to most of their daily activities. In all, 22 patients had neurological improvement (tables 2, and 3): 3 with antibodies to intracellular antigens ( $\mathrm{Ma} 2, \mathrm{n}=2 ; \mathrm{Hu}, \mathrm{n}=1), 12$ to nCMAg, 4 to VGKC and 3 without antibodies. Of these 22 patients, 15 $(\mathrm{Hu}, \mathrm{n}=1$; nCMAg, $\mathrm{n}=7$; VGKC, $\mathrm{n}=4$; and no antibodies, $\mathrm{n}=3$ ) completely improved and the other seven partially improved. Of the 13 patients who had clinical stabilisation $(n=3)$ or deterioration $(n=10), 9$ had antibodies to intracellular antigens, 3 to nCMAg and 1 to VGKC. When compared with patients with antibodies to intracellular antigens, those with antibodies to cell-membrane antigens in general (including nCMAg and VGKC) were more likely to have neurological improvement $(\mathrm{p}=0.003)$. A similar strong association with improvement was found in the subgroup of patients with antibodies to nCMAg $(\mathrm{p}=0.006)$.

\section{DISCUSSION}

In the past 4 years, we prospectively identified 17 patients with limbic encephalitis in a single institution. A remarkable finding is that $9(53 \%)$ of these patients had antibodies to previously known antigens and $5(29 \%)$ to nCMAg. Considering these patients and those whose serum or CSF samples were sent to us for analysis, 19 of $39(49 \%)$ patients had antibodies known to be associated with limbic encephalitis (paraneoplastic or VGKC). However, 17 of 39 (44\%) patients had antibodies to diverse nCMAg that are not measured by currently available commercial tests and were not included in the recently reported diagnostic criteria of paraneoplastic syndromes. ${ }^{17}$ This finding is important because the disorders associated with cell-membrane antigens in general (either VGKC or nCMAg) are usually responsive to treatment and have a definitely better prognosis than those associated with intracellular antigens. Correlation between antibody titres and improvement was not determined in this study, ${ }^{78}$ partly because the nCMAg antibodies are predominantly found in the CSF and repeat spinal taps were not obtained after improvement in these patients.

A review of a previous series of patients with autoimmune limbic encephalitis shows that most did not adequately reflect the clinical-immunological spectrum of the disorder because of the following:

1. Cases were identified from retrospective review of patients known to have cancer ${ }^{11}$

2. Laboratories tested sera or CSF samples selected at multiple institutions $^{1}$

3. The inclusion criteria were restricted to patients with a specific type of cancer or antibody. ${ }^{4} 18$

None of these biases pertains to the 15 patients in our study who were identified on clinical grounds at the HUP and who provide a relative distribution of immunophenotypes in limbic encephalitis.

However, a referral bias was noted in the 22 patients whose sera or CSF samples were sent to us for analysis. The referral pattern seemed to be driven by our recent reports on subtypes of limbic encephalitis. ${ }^{810}$ Of the 22 patients, 17 (77\%) had anti-Ma2 (23\%) or antibodies to nCMAg (54\%). By contrast, the frequency of anti-Ma2 encephalitis in patients in HUP was markedly lower $(6 \%)$, while the occurrence of limbic encephalitis with antibodies to nCMAg remained relatively high (29\%). Antibodies to nCMAg were found more frequently than antiVGKC (18\%), suggesting that many patients who are considered to have idiopathic or "non-herpetic limbic encephalitis without VGKC antibodies" ${ }^{19}$ may indeed have antibodies to nCMAg.

In light of the increasing number of reports on patients with limbic encephalitis and anti-VGKC, it can be argued that these patients are under-represented or were missed in our study. This is unlikely for two reasons: (1) the clinical and MRI picture of these patients with either predominant limbic encephalitis or Morvan's syndrome is no more difficult to recognise than the 
immunophenotypes reported here; and (2) all samples from patients without antibodies to intracellular antigens were examined for anti-VGKC using at least two and in some cases three different methods (radioimmunoassay, immunohistochemistry with brain tissue, and immunocytochemistry with cells expressing Kv subunits). Although the five patients with anti-VGKC were positive by all methods used (three patients examined with all three methods), the 17 patients with antibodies to nCMAg were negative by all methods, except for two patients who showed faint reactivity with cells expressing Kvl.4 in one case and Kvl.6 in the other. In both instances, the reactivity with brain was clearly different from polyclonal Kvl.4 and Kvl.6 antibodies (data not shown), indicating that the presence of antibodies to other antigens was more restricted to the hippocampus. In previously reported patients with limbic encephalitis with anti-VGKC, the prominent antigen was Kvl.1, ${ }^{16}$ and this was also found in our three patients with anti-VGKC in whom the subunit specificity was determined.

These findings have important clinical implications:

1. Besides the known antibodies associated with limbic encephalitis (paraneoplastic or VGKC), there is an emerging group of patients with treatment-responsive limbic encephalitis.

2. These disorders are associated with antibodies that predominantly react with the neuropil of the hippocampus and may occur without or with a tumour association.

3. Among all subphenotypes, there is a group of young women who have apparently benign ovarian cysts, but pathological studies show mature or immature teratoma. ${ }^{8}$ The importance of recognising these patients is that they may transiently improve with immunotherapy, but preliminary experience suggests that recovery depends on both tumour removal and immunotherapy ${ }^{20} 21$ (manuscript in preparation).

4. At presentation, there are no neurological, MRI or CSF features specific of any immunophenotype, except for the predominant type of tumour in some paraneoplastic disorders (ie, Ma2 and testicular cancer; $\mathrm{Hu}$ and smallcell lung cancer), or the low likelihood of cancer in patients with anti-VGKC. ${ }^{4}$

The generally favourable outcome in most patients with antibodies to cell-membrane antigens (either VGKC or nCMAg) validates a previously suggested approach for the management of patients with limbic encephalitis. ${ }^{22}$ After reasonable exclusion of other disorders (ie, herpes simplex virus encephalitis was diagnosed in 26 patients during the same 4-year period at the HUP), patients suspected of having autoimmune limbic encephalitis should be considered for immunotherapy (corticosteroids, intravenous immunoglobulin or plasma exchange). Treatment should start even in the absence of antibody testing because patients with limbic encephalitis-VGKC or ovarian teratoma can deteriorate rapidly, with status epilepticus, hyponatraemia or hypoventilation that may result in death. Also, some patients with limbic encephalitis of unclear aetiology or without antibodies may show dramatic response to corticosteroids, as found in three of our patients.

\section{ACKNOWLEDGEMENTS}

We thank all the doctors at the Hospital of the University of Pennsylvania, particularly the Neurology residents, for their thorough evaluations and awareness of paraneoplastic neurologiccal disorders; and Dr Erdem Tüzün for critically reviewing the manuscript. We also thank the doctors who provided clinical information on patients diagnosed at other institutions.

\section{Authors' affiliations}

L Bataller, G F Wu, J E Rossi, M R Rosenfeld, J Dalmau, Hospital of the

University of Pennsylvania, Philadelphia, Pennsylvania, USA

K A Kleopa, The Cyprus Institute of Neurology and Genetics, Nicosia,

Cyprus

Funding: This study was supported in part by grants RO1CA89054 and RO1CA107192 (to JD) and a National Multiple Sclerosis Society grant (to KAK).

Competing interests: None declared.

\section{REFERENCES}

1 Gultekin SH, Rosenfeld MR, Voltz R, et al. Paraneoplastic limbic encephalitis: neurological symptoms, immunological findings and tumor association in 50 patients. Brain 2000;123:1481-94.

2 Bien CG, Schulze-Bonhage A, Deckert M, et al. Limbic encephalitis not associated with neoplasm as a cause of temporal lobe epilepsy. Neurology 2000;55:1823-8.

3 Watanabe $Y$, Shimizu Y, Ooi S, et al. Steroid-responsive limbic encephalitis. Intern Med 2003;42:428-32.

4 Vincent A, Buckley C, Schott JM, et al. Potassium channel antibody-associated encephalopathy: a potentially immunotherapy-responsive form of limbic encephalitis. Brain 2004;127:701-12.

5 Stubgen JP. Nervous system lupus mimics limbic encephalitis. Lupus 1998;7:557-60

6 Mochizuki Y, Mizutani T, Isozaki E, et al. Acute limbic encephalitis: a new entity? Neurosci Lett 2006;394:5-8.

7 Ances BM, Vitaliani R, Taylor RA, et al. Treatment-responsive limbic encephalitis identified by neuropil antibodies: MRI and PET correlates. Brain 2005; 128:1764-77.

8 Vitaliani R, Mason W, Ances B, et al. Paraneoplastic encephalitis, psychiatric symptoms, and hypoventilation in ovarian teratoma. Ann Neurol 2005;58:594-604.

9 Alamowitch S, Graus F, Uchuya M, et al. Limbic encephalitis and small cell lung cancer. Clinical and immunological features. Brain 1997;120:923-8.

10 Dalmau J, Graus F, Villarejo A, et al. Clinical analysis of anti-Ma2-associated encephalitis. Brain 2004;127:1831-44.

11 Lawn ND, Westmoreland BF, Kiely MJ, et al. Clinical, magnetic resonance imaging, and electroencephalographic findings in paraneoplastic limbic encephalitis. Mayo Clin Proc 2003;78:1363-8.

12 Pozo-Rosich P, Clover L, Saiz A, et al. Voltage-gated potassium channel antibodies in limbic encephalitis. Ann Neurol 2003;54:530-3.

13 Fadul CE, Stommel EW, Dragnev KH, et al. Focal paraneoplastic limbic encephalitis presenting as orgasmic epilepsy. J Neurooncol 2005;72:195-8.

14 Dalmau J, Furneaux HM, Gralla RJ, et al. Detection of the anti-Hu antibody in the serum of patients with small cell lung cancer-a quantitative western blot analysis. Ann Neurol 1990;27:544-52.

15 Mason WP, Graus F, Lang B, et al. Small-cell lung cancer, paraneoplastic cerebellar degeneration and the Lambert-Eaton myasthenic syndrome. Brain 1997; 120:1279-300

16 Kleopa KA, Elman LB, Lang B, et al. Neuromyotonia and limbic encephalitis sera target mature Shaker-type K+ channels: subunit specificity correlates with clinical manifestations. Brain 2006;129:1570-84.

17 Graus F, Delattre JY, Antoine JC, et al. Recommended diagnostic criteria for paraneoplastic neurological syndromes. J Neurol Neurosurg Psychiatry 2004;75: 1135-40.

18 Rosenfeld MR, Eichen JG, Wade DF, et al. Molecular and clinical diversity in paraneoplastic immunity to Ma proteins. Ann Neurol 2001;50:339-48.

19 Shoji H, Asaoka K, Ayabe M, et al. Non-herpetic acute limbic encephalitis: a new subgroup of limbic encephalitis? Intern Med 2004;43:348.

20 Muni RH, Wennberg R, Mikulis DJ, et al. Bilateral horizontal gaze palsy in presumed paraneoplastic brainstem encephalitis associated with a benign ovarian teratoma. I Neuroophthalmol 2004;24:114-18.

21 Nokura K, Yamamoto H, Okawara Y, et al. Reversible limbic encephalitis caused by ovarian teratoma. Acta Neurol Scand 1997;95:367-73.

22 Darnell RB, Posner JB. A new cause of limbic encephalopathy. Brain $2005 ; 128: 1745-6$ 